\title{
Distrubution of Antibiotic Resistance in Urinary Tract Infections in Children; a Five-Year Evaluation
}

\author{
çocuklarda Idrar Yolu Enfeksiyonlarında Antibiyotik Direnç Dağıımı; \\ BeşYıllık Bir Değerlendirme
}

\author{
Hayrunnisa Bekis Bozkurt(ID), Çiğdem Eda Balkan²(ID) \\ ${ }^{1}$ Department of Pediatrics, Kafkas University School of Medicine, Kars, Turkey \\ ${ }^{2}$ Department of Medical Microbiology, Kafkas University School of Medicine, Kars, Turkey
}

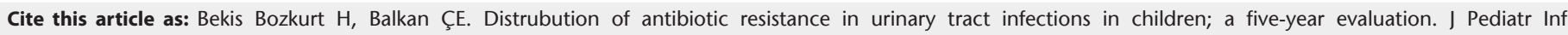
2020;14(3):e129-e137.

Abstract

Objective: In our study, we aimed to evaluate the prevalence of microorganisms, antibiotic resistance rates, and changes over a five-year period in order to plan timely and appropriately the treatment of urinary tract infections in children.

Material and Methods: In this retrospective study, data were obtained by screening the microbiology laboratory records from the automation system of our hospital. Urine samples were collected by the midstream urine or bag culture. 105 colonies with a single microorganism in a urine culture were evaluated as positive urine culture. A total of 4938 urine cultures were retrospectively screened over a five-year period.

Results: Of the total 613 (12.4\%) positive urine cultures, $83.4 \%$ were identified as gram-negative and $16.6 \%$ as gram-positive. The most common bacteria in gram-negative growth was Escherichia coli (68.3\%), followed by Proteus spp. (16.4\%) and Klebsiella spp. (10.6\%). The most common bacteria in gram-positive agents was Enterococcus spp. $42.2 \%$. While the ratio of the extended-spectrum beta-lactamase (ESBL) (+) organisms in 2013 was $9 / 96$ (9.4\%), it was found to be $22 / 102(21.6 \%)$ in 2017. The highest ampicillin resistance was observed in Klebsiella strains (79.6\%) and the lowest in Proteus strains (44\%). Increased ampicillin resistance $(54.2 \%$ to $66.7 \%)$ and decreased trimethoprime/sulfamethoxazole resistance (54.2\% to $45.1 \%$ ) were found over the years.

Conclusion: We think that aminoglycosides and nitrofurantoin can be effectively used as an alternative option in empirical treatment due to increased resistance to ESBL, ampicillin, and amoxicillin clavulanate. Antibiotic selection should be customized according to the results of urine culture antibiogram.

Keywords: Antibiotic resistance, child, urinary tract infections
Öz

Giriş: Çalışmamızda çocukluk çağında görülen üriner sistem enfeksiyonlarının zamanında ve uygun tedavisini planlayabilmek için son 5 yıl içindeki etken mikroorganizmaları, antibiyotik direnç oranlarını ve yıllar içindeki değiş̧imini değerlendirmeyi amaçladık.

Gereç ve Yöntemler: Çalışmamızda, veriler hastanemiz otomasyon sisteminden mikrobiyoloji laboratuvar kayıtları taranarak elde edildi. İdrar kültürleri orta akım veya torba kültürü ile toplandı. İdrar kültürlerinde tek bir mikroorganizmada 105 koloni üreme olması pozitif idrar kültürü olarak değerlendirildi. Beş yıllık sürede toplam 4938 idrar kültürü geriye dönük olarak tarandı.

Bulgular: Gram-negatif (\%83.4) ve gram-pozitif (\%16.6) etkenlerden olmak üzere toplam 613 (\%12.4) pozitif idrar kültürü tespit edildi. Gram-negatif üreyen etkenlerde en fazla Escherichia coli \%68.3 oranında bulunurken, bunu Proteus spp. \%16.4, Klebsiella spp. \%10.6 oranı ile takip etti. Gram-pozitif etkenlerde ise en fazla Enterococcus spp. \%42.2 oranılla görüldü. Genişlemiş spektrumlu beta-laktamaz (GSBL) (+) organizmaların oranı 2013 yılında \%9.4 (9/96) iken 2017 yılında bu oranın \%21.6 (22/102)'ya çıktığı tespit edildi. Ampisilin direnci en yüksek Klebsiella suşlarında (\%79.6) görülürken en düşük (\%44) Proteus suşlarında görüldü. Yıllar içinde ampisilin direncinde artış (\%54.2'den \%66.7'ye), trimetoprim-sülfametoksazol direncinde azalma (\%54.2'den \%45.1'e) olduğu belirlendi.

Sonuç: Hastanemizde GSBL direncinin artması, yüksek oranda ampisilin, amoksisilin-klavulanik asit direnci, \%24 civarında bulunan seftriakson direnci nedeniyle aminoglikozidlerin ve nitrofurantoinin ampirik tedavide tercih edilebileceğini düşünüyoruz. Antibiyotik seçiminin idrar kültür antibiyogram sonucuna göre özelleştirilmesi ve akılcı antibiyotik kullanımına yönelinilmesi gerekir.

Anahtar Kelimeler: Antibiyotik direnci, çocuk, üriner sistem enfeksiyonları

\section{Correspondence Address/Yazışma Adresi}

\section{Çiğdem Eda Balkan}

Kafkas Üniversitesi Araştırma ve Uygulama Hastanesi,

Tıbbi Mikrobiyoloji Laboratuvarı,

Kars-Türkiye

E-mail: cigdemedabalkan@gmail.com 


\section{Introduction}

Urinary tract infections (UTIs) are among the most common infections in childhood and an important cause of morbidity. Failure to properly and timely treat these infections with appropriate antibiotics can lead to serious consequences, such as renal failure, high blood pressure, and retardation in growth and development $(1,2)$. UTIs are difficult to diagnose since they may occur with non-specific symptoms during infancy (3). Empirical treatment is recommended for these patients due to complications known in clinical practice. Most commonly, ampicillin, amoxicillin clavulanic acid, trimethoprim-sulfamethoxazole (TMP-SMX) and cephalosporin group antibiotics are preferred in empiric treatment (4). However, it is well evidenced that empiric treatments eventually lead to severe antibiotic resistance (5). Therefore, it is necessary to investigate the organisms and antibiotic resistance of UTIs in different geographical regions to determine the appropriate antibiotic in order to significantly reduce morbidity and mortality. The aim of our study was to identify the optimum antibiotic regimen for our region by investigating the microorganisms that caused UTIs in the study area, the antibiotic resistance rates, and changes over a fiveyear period.

\section{Materials and Methods}

After obtaining the approval of the regional ethics committee (25.07.2018/80576354-050-99/144), patients, aged 0-16 years, admitted to the pediatric outpatient clinic of our hospital between January 1, 2013 and January 1, 2018 were included in the study. Data were obtained by screening the microbiology laboratory records from the automation system of our hospital. The urine samples were kept in $5 \%$ blood agar and eosin methylene blue agar (EMB) for $18-24$ hours at $37^{\circ} \mathrm{C}$. The microorganisms reproducing in culture were identified by a conventional method using the IMVIC tests. Antibiotic susceptibilities were determined by the Kirby-Bauer disk diffusion method on the Mueller-Hinton agar based on the EUCAST criteria. The Phoenix system (PHX) was used for manually unidentifiable bacteria. PHX is a fully automated system for the rapid identification of bacteria and antimicrobial susceptibility testing. The presence of $10^{5}$ colonies with a single microorganism was evaluated as positive urine culture. Urine samples were collected by the midstream urine or bag culture. Urine was collected with bag culture in children under 2 years old or who were not toilet trained yet. In children over the age of 2 or with toilet training, instructions were explained to their families and urine was collected by taking clean midstream urine. Patients with recurrent UTIs or urinary tract anomalies, those that required urinary catheters, and those that were in intensive care unit were excluded from the study. A total of 4.938 urine cultures were retrospectively screened over a fiveyear period. Since only samples sent to the laboratory were studied, patient consent was not required.

\section{Statistical Analysis}

The Statistical Package for the Social Sciences (SPSS ver. 20.0 Inc. Chicago, IL, USA) 22.0 package proGram was used for all statistical evaluations. The Kolmogorov-Smirnov test was conducted to test the normality assumption, and descriptive and frequency analyses and the chi-square test were used for the comparison of categorical variables.

\section{Results}

A total of 4.938 urine samples obtained from patients aged 1 month to 16 years were analyzed. Growth was seen in 613 samples (12.4\%), of which $83.4 \%$ were gram-negative and $16.6 \%$ were gram-positive. The number of male and female patients with positive urine cultures was 251 (40.9\%) and $362(59.1 \%)$, respectively. The age of the patients was $55.11 \pm 48.18$ months. While $38.7 \%$ of the patients were $\leq 2$ years old, $61.3 \%$ were over two years of age. The proportion of boys under two years was greater than girls at $57 \%$, while the ratio of girls over two years of age was $72.6 \%$.

The microorganisms identified were Escherichia coli in 60\% of the patients $(n=349)$, Proteus spp. in $15 \%(n=84)$, Klebsiella spp. in $9 \%(n=54)$, and Enterococcus spp. in $8 \%(n=43)$ (Figure 1). Gram-negative bacteria were the most frequent isolates, with E. coli $68.3 \%$ being the most common, followed by Proteus spp. and Klebsiella spp. at $16.4 \%$ and $10.6 \%$, respectively. The increase in Klebsiella strains was statistically significant over the years $(p=0.00)$ (Table 1). Extended-spectrum beta-lactamase (ESBL) positivity was not detected in gram-positive bacteria and was only found in gram-negative bacteria. The incidence of ESBL positivity was $14.9 \%$ for E. coli and $7.4 \%$ for Klebsiella spp. While the ratio of ESBL (+) organisms was 9/96 (9.4\%) in 2013, it increased to 22/102 (21.6\%) in 2017 (Figure 2). In gram-positive microorganisms, Enterococcus was the most common agent seen at a rate of $42.2 \%$, followed by coagulase-negative staphylococcus (CNS) at $23.5 \%$, Staphylococcus aureus at 22.5\%, and Streptococcus spp. at 7.8\%. Over the fiveyear period, the number of methicillin-resistant strains increased (Table 2). No distinction between agent and contamination was made in CNS. Urine culture was only requested for patients with clinical suspicion. In order to prevent contamination, the patients were asked to wash the area with soapy water before urination. Antiseptics were not considered as appropriate to use before urine collection as it could cause false negatives.

Among the gram-negative bacteria, there was high resistance to ampicillin, amoxicillin clavulanate, and TMP-SMX at rates of $58.3 \%, 28 \%$, and $42.2 \%$ respectively, while there was low resistance to amikacin, meropenem, piperacillin at 3.1\%, $4.1 \%$, and $2.2 \%$, respectively. Gentamicin resistance was seen in $7.4 \%$ of the patients and ceftriaxone resistance in $20.7 \%$. The incidence of ampicillin resistance increased from 54.2 to 


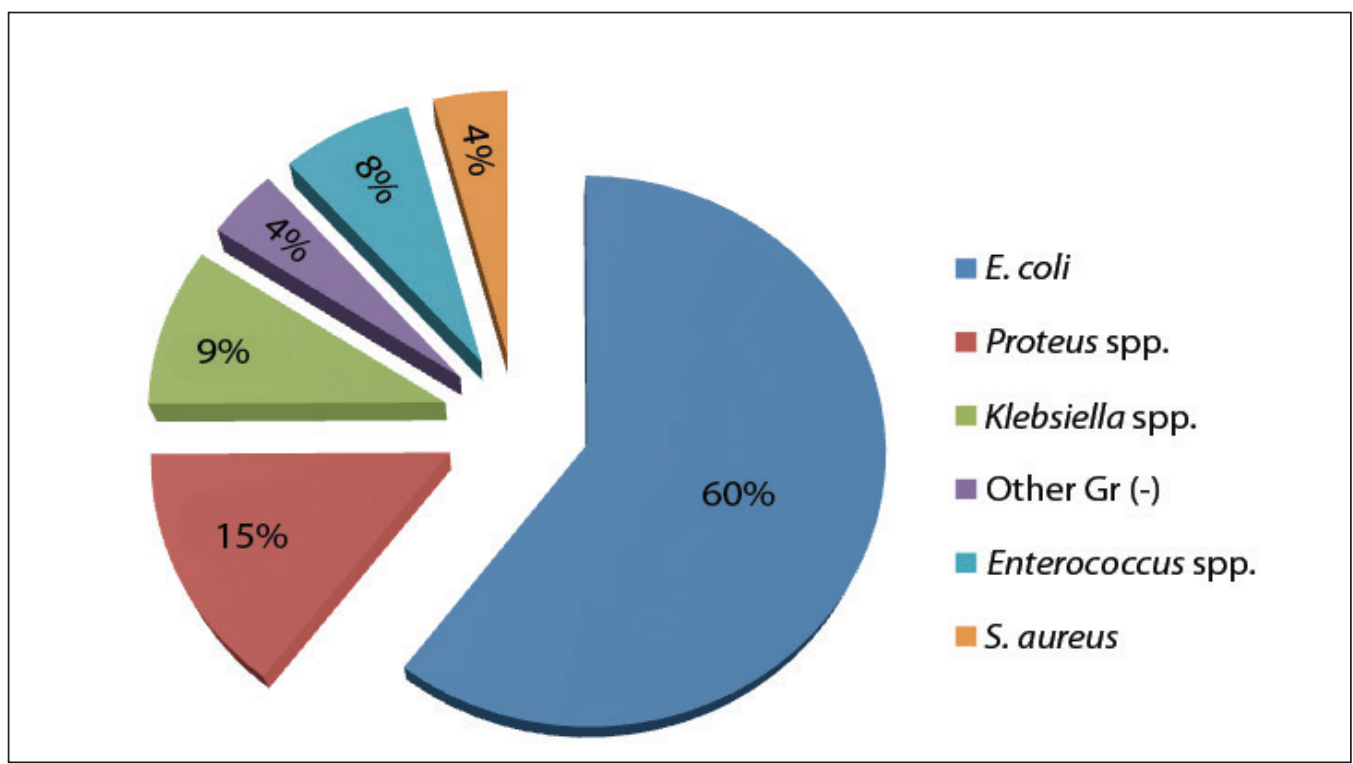

Figure 1. Distribution of microorganisms isolated from urine cultures.

Table 1. Distribution of gram-negative bacteria by years

\begin{tabular}{|c|c|c|c|c|c|c|}
\hline & $2013(n)$ & $2014(n)$ & $2015(n)$ & $2016(n)$ & $2017(n)$ & Total \\
\hline Escherichia coli & 62 & 86 & 71 & 67 & 63 & 349 \\
\hline Proteus spp. & 21 & 9 & 16 & 21 & 17 & 84 \\
\hline Klebsiella spp. & 8 & 4 & 8 & 17 & 17 & 54 \\
\hline Pseudomonas aeruginosa & 1 & 3 & 3 & 0 & 3 & 10 \\
\hline Diğer* & 4 & 5 & 0 & 3 & 2 & 14 \\
\hline Toplam & 96 & 107 & 98 & 108 & 102 & 511 \\
\hline
\end{tabular}

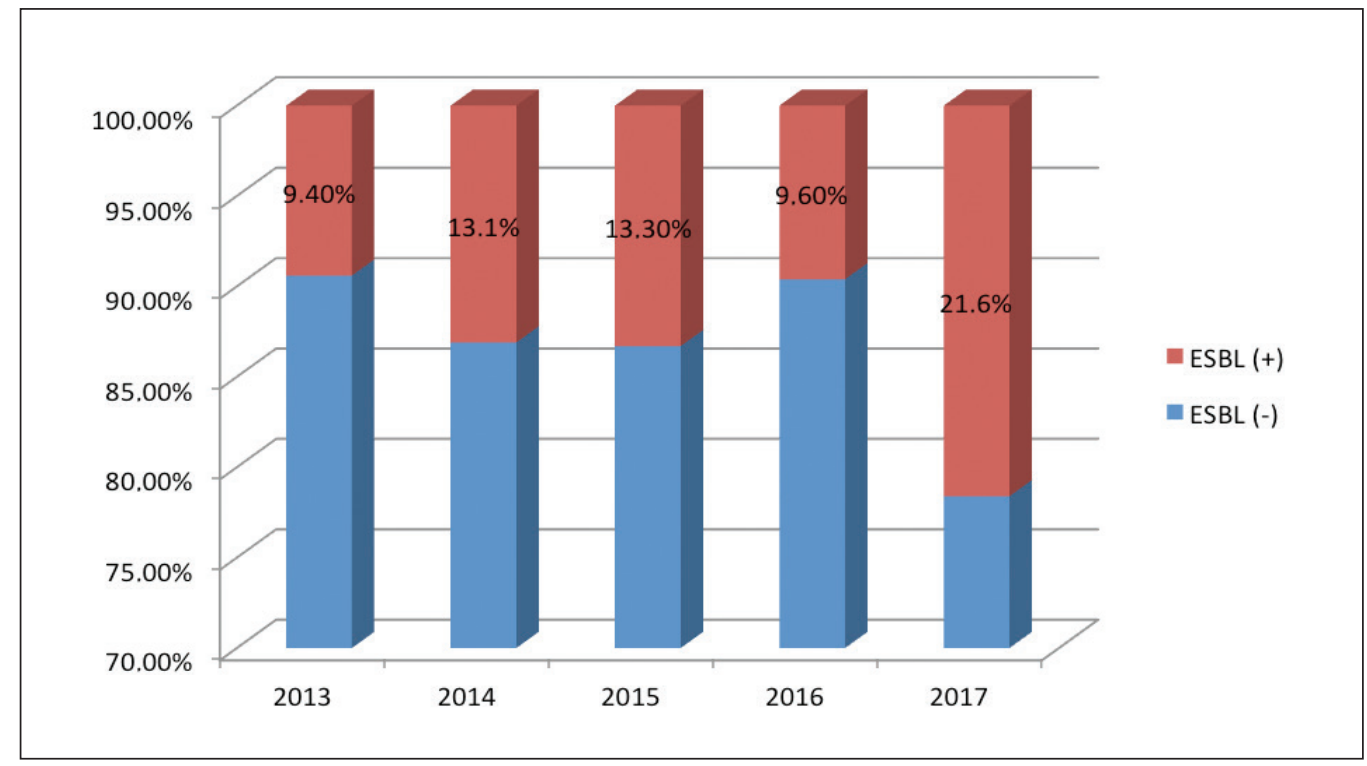

Figure 2. ESBL positivity over five years. 
Table 2. Distribution of gram-positive bacteria by years

\begin{tabular}{|c|c|c|c|c|c|c|}
\hline & $2013(n)$ & $2014(n)$ & $2015(n)$ & $2016(n)$ & $2017(n)$ & Total \\
\hline Enterococcus spp. & 12 & 15 & 9 & 4 & 3 & 43 \\
\hline MSKNS/MRKNS* & $7(7 / 0)$ & $3(3 / 0)$ & $2(2 / 0)$ & $5(3 / 2)$ & $7(4 / 3)$ & 24 \\
\hline Streptococcus spp. & 2 & 1 & 0 & 5 & 0 & 8 \\
\hline Other ${ }^{* * *}$ & 1 & 1 & 2 & 0 & 0 & 4 \\
\hline
\end{tabular}

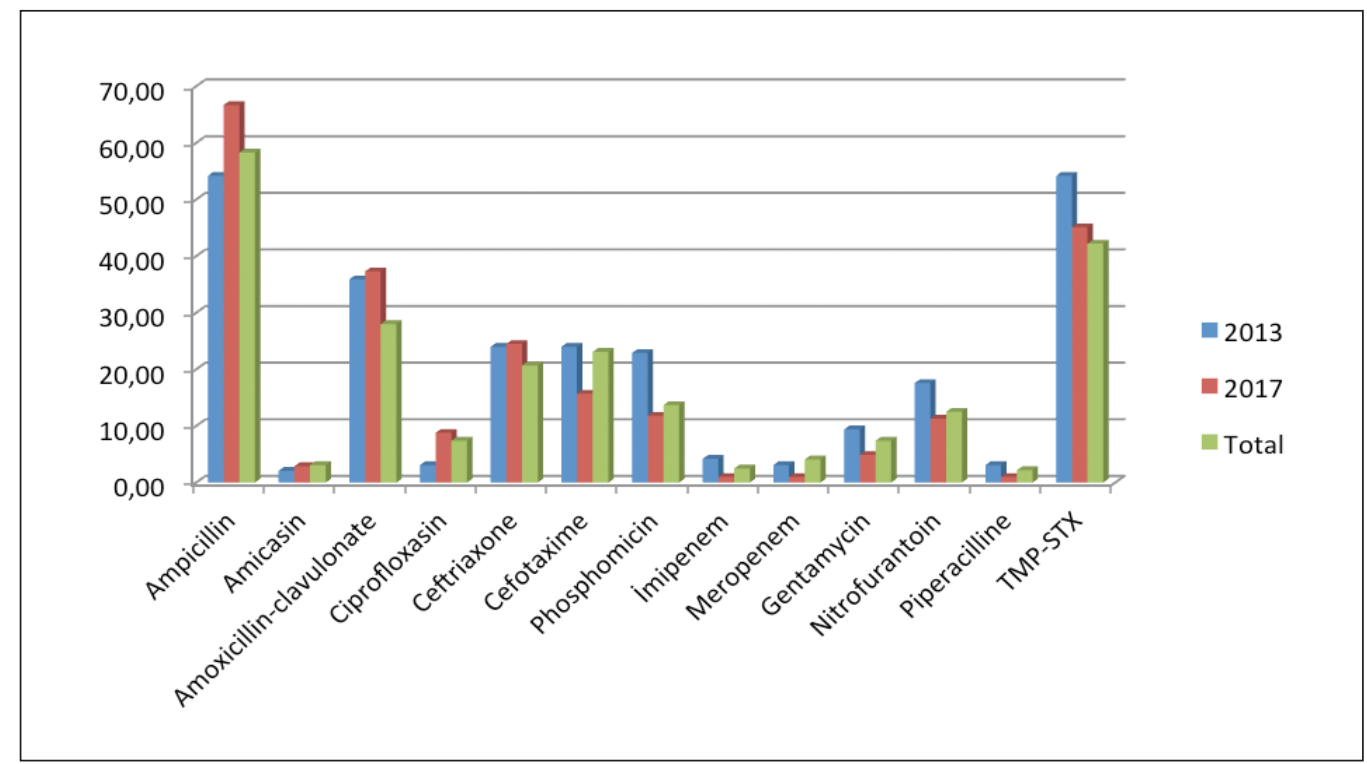

Figure 3. Antibiotic resistance of gram-negative bacteria over five years.

$66.7 \%$ over the five years while TMP-SMX resistance was reduced from 54.2 to $45.1 \%$, phosphomycin resistance from 22.9 to $11.8 \%$, cefotaxime resistance from 24 to $15.7 \%$, and gentamicin resistance from 9.4 to $4.9 \%$ (Figure 3 ).

When antibiotic resistance rates of the most common gram-negative microorganisms were investigated, ampicillin resistance in $E$. coli strains was $57.6 \%$, amikacin resistance was $2.1 \%$, amoxicillin-clavulanate resistance was $29.1 \%$, and TMPSMX resistance was 57.2\%. For the Proteus strains, amikacin resistance was seen at a rate of $6.1 \%$, cefotaxime resistance at $21.4 \%$, and TMP-SMX resistance at 54.8\%. Ampicillin resistance had the highest incidence among Klebsiella strains (79.6\%) and the lowest in Proteus strains (44\%). Piperacillin resistance was not detected in any of the Proteus strains, while it was found in $1.9 \%$ of the E. coli strains and $2.6 \%$ of Klebsiella spp. Nitrofurantoin resistance was most common in E. coli at $5.6 \%$. Ceftriaxone resistance was also most frequently seen in E. coli at $24.4 \%$, but phosphomycin resistance had the highest incidence in Proteus strains at $15.5 \%$ (Table 3 ).
In gram-positive bacteria, resistance to penicillin, ampicillin, erythromycin, cefoxitin, clindamycin, and TMP-SMX was found to be $55.6 \%, 48.5 \%, 49.5 \%, 32.3 \%, 39.6 \%$, and $44.1 \%$, respectively. Vancomycin, linezolid and cefepime resistance was low, seen in $1 \%, 7.1 \%$ and $8.6 \%$ of the samples, respectively. Over the five years, penicillin, ampicillin, erythromycin, cefoxitin and clindamycin resistance was found to decrease (Figure 4). Since only samples sent to the laboratory were studied retrospectively, patient consent was not required.

\section{Discussion}

UTIs are among the most common infections in children. They can lead to significant complications if not treated timely with appropriate antibiotics. Since they constitute an important cause of morbidity when untreated, empiric treatment is recommended. Amoxicillin-clavulanate, TMPSMX, cefuroxime, and cefixime are the most commonly used agents for oral treatment while ceftriaxone, cefotaxime, gentamicin, and piperacillin are mostly preferred for parenteral treatment. However, empiric treatment has brought along 
Table 3. Antibiotic resistance rates of the most common gram-negative bacteria

\begin{tabular}{|c|c|c|c|}
\hline & Escherichia coli \% & Proteus spp. \% & Klebsiella spp. \% \\
\hline Ampicillin & 57.6 & 44 & 79.6 \\
\hline Amikacin & 2.1 & 6.1 & 3.7 \\
\hline Cefotaxime & 22.9 & 21.4 & 27.8 \\
\hline Ceftriaxone & 24.4 & 9.5 & 27.8 \\
\hline Ertapenem & 6 & 2.4 & 5.6 \\
\hline Imipenem & 2 & 1.8 & 1.9 \\
\hline Phosphomycin & 13.2 & 15.5 & 13 \\
\hline Gentamicin & 6.3 & 9.5 & 9.3 \\
\hline Nitrofurantoin & 5.2 & 13.6 & 16.7 \\
\hline Levofloxacin & 8.7 & 3.6 & 1.9 \\
\hline Piperacillin & 2.6 & 0 & 1.9 \\
\hline TMP-SMX & 57.2 & 54.8 & 64.8 \\
\hline
\end{tabular}

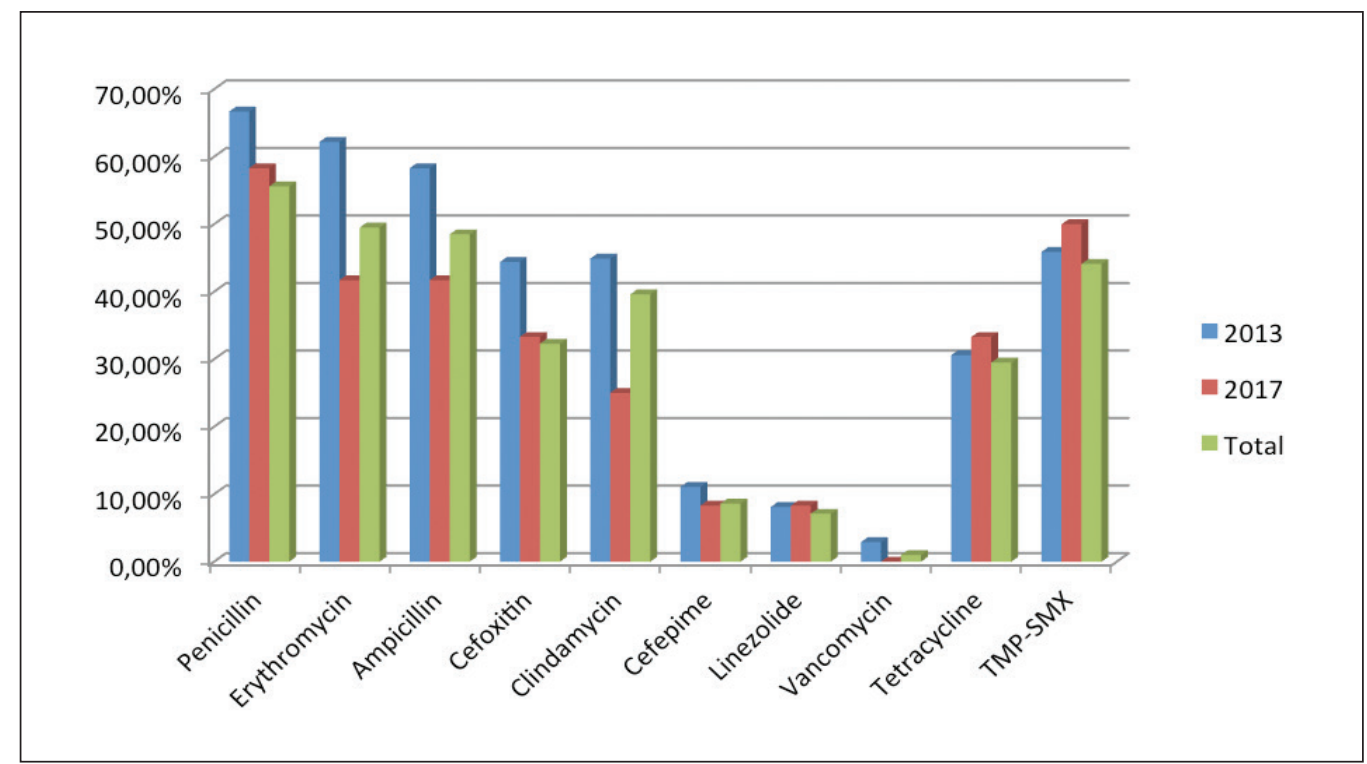

Figure 4. Antibiotic resistance of gram-positive bacteria over five years.

the problem of antibiotic resistance over time (5-7). Therefore, it is important to determine the patient's age, sex, regionally the most common microorganism, and antibiotic resistance rate.

UTIs are more common in girls than in boys. However, in younger children (under two years), the situation is the opposite (8). In the current study, $59.1 \%$ of the patients were females. In boys under two years of age, UTIs were more common at $57 \%$, whereas over two years, this rate was $72.3 \%$ in girls. The age range of our patients was 1 month-16 years (mean 55 months).

The most common cause of UTIs in children are gram-negative bacilli with E. coli being the most frequent agent (9). Although $E$. coli is the most common bacteria in many studies conducted in Turkey, the second and third frequent bacteria vary according to the geographical region. In our study, we detected the second most common agent as Proteus spp. and the third as Klebsiella spp., which is consistent with the 
reports of Ipek et al. and Senel et al. $(10,11)$. In some studies, Klebsiella spp. take the second place, while Enterobacter spp. rank third $(12,13)$. In another study, CNS were found to be the second most common bacteria (14). In the current study, we determined the most common agent among gram-positive bacteria as Enterococcus. Despite the availability of similar data in the literature, there are also studies that have reported CNS and S. aureus strains to be the most common gram-positive bacteria $(15,16)$. We also found an increase in Klebsiella strains and methicillin-resistant forms of Staphylococcus spp. over the years. The resistance of Klebsiella strains to common antibiotics was higher than E. coli. These two findings suggest that rational antibiotic use should be encouraged.

Another problem was the increase in ESBL-positive bacteria. The production of beta-lactamase is one of the most important resistance mechanisms of gram-negative bacteria against beta-lactam antibiotics. If a bacterium is synthesizing beta-lactamase, it can cleave the amide bonds in the beta-lactam ring of the beta-lactam group of antibiotics and make this antibiotic ineffective. This acquired property can be synthesized by the genetic structure of the bacteria and transferred (17). In studies, ESBL positivity in E. coli isolates has ranged from $13 \%$ to $20.8 \%$ of the urine cultures while a meta-analysis has reported that ESBL incidence reached $28.4 \%$ (18-20). In our study, ESBL positivity was $14.9 \%$ for $E$. coli strains and $7.4 \%$ for Klebsiella strains, and it was $9.4 \%$ in 2013 and $21.6 \%$ in 2017. Although this is consistent with the literature, the increase over the years is worrying.

In gram-negative bacteria, resistance to ampicillin, amoxicillin-clavulanate, and TMP-SMX, which are the most preferred oral drugs, has been reported to be high in many studies (21-27). In the current study, in agreement with the literature, ampicillin resistance was found to be $57.6 \%$, amoxicillin-clavulanate resistance was $29.1 \%$, and TMP-SMX resistance was $57.2 \%$ in E. coli strains. The highest ampicillin resistance was observed in Klebsiella strains (79.6\%) and the lowest in Proteus strains (44\%). In previous studies, the ampicillin resistance rate of Klebsiella strains has been reported to be $93.2 \%$ by Çoban et al., $88.2 \%$ by Güner et al., $67 \%$ by Mir et al., and $76 \%$ by Yaşar et al. (24,27-29). Although there was an increase in ampicillin resistance in our study, TMP-SMX resistance decreased but remained high at $45.1 \%$ in 2017 . On the other hand, it was positive to see that phosphomycin, cefotaxime and gentamicin resistance had decreased.

In this study, gram-negative bacteria had the lowest resistance to amikacin, meropenem and piperacillin, and oral nitrofurantoin. Before 2010, there were studies reporting no meropenem and amikacin resistance. However, in recent studies, resistance to these agents has been reported with increasing frequency. Our results were in agreement with those reported in studies conducted in Turkey $(30,31,33)$. Most common bacteria and antibiotic resistance rates in some recent studies are listed in Table 4.

We found among the gram-positive agents that resistance to penicillin, ampicillin and TMP-SMX was high; whereas, vancomycin, linezolid and cefepime resistance was low. In studies conducted, while penicillin resistances are generally high, ampicillin resistances vary from region to region. In a study by Kalal et al., the ampicillin and ciprofloxacin resistance of Enterococcus strains has been determined as $87.5 \%$ and $75 \%$, respectively while these rates have been found as $20 \%$ for both antibiotics in the study by Saeed et al. $(32,34)$. Özdem et al. have not found vancomycin resistance, but observed ampicillin resistance at a rate of $6.3 \%$, penicillin resistance at $47.2 \%$ and TMP-SMX resistance at $14.8 \%$ (35). Similarly, Yenişehirli et al. havew found no resistance to vancomycin, but calculated ampicillin, penicillin and ciprofloxacin resistance rates as $8.7 \%, 60.9 \%$ and $15.2 \%$, respectively (36). Vancomycin-resistant enterococci strains present as an important problem, especially in patients in intensive care, with significant risk factors being the use of multiple parenteral antibiotics, application of invasive procedures, and underlying secondary diseases $(37,38)$. Vancomycin resistance is not expected in patients referred from outpatient clinics (39). In the current study, patients with recurrent UTIs, those receiving intensive care, and those that required the use of a catheter were not included. We found vancomycin resistance and cefepime resistance rates to be low at $1 \%$ and $9.2 \%$, respectively, but ampicillin resistance was higher than previously reported in studies conducted in Turkey. A positive finding was that penicillin, ampicillin and cefoxitin resistance was observed to decrease over the five years. However, the presence of vancomycin resistance albeit at low rates and high resistance to common antibiotics (ampicillin, TMP-SMX) were concerning.

A limitation of our study was that we were not able to evaluate the symptoms and findings of the patients when they gave the urine samples; thus, there was the possibility of growth with incompatible with the clinical findings. Another limitation was that the collected urine was not removed by catheter or by suprapubic aspiration. So, the risk of contamination was high due to the midstream urine or bag culture.

This is the first comprehensive study conducted in our region investigating urine culture and antibiotic resistance of children. Based on the results we obtained, we consider that aminoglycosides and nitrofurantoin should be preferred in empirical treatment due to the increased resistance to ESBL, ampicillin, amoxicillin clavulanate, and ceftriaxone. Antibiotic selection should be customized according to the results of urine culture antibiogram and rational antibiotic use should be encouraged considering the high rates of unnecessary use of antibiotics. Our study could be further elaborated by eliminating contamination. Biochemical markers will be useful for future studies. 


\begin{tabular}{|c|c|c|c|c|c|c|c|c|c|c|c|c|c|c|c|}
\hline 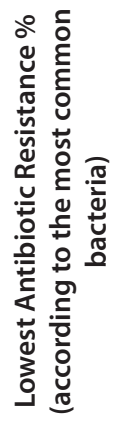 & 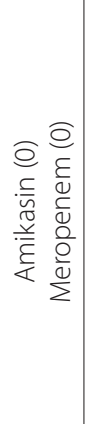 & 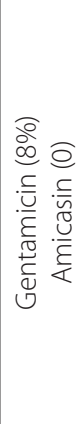 & 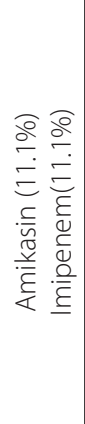 & 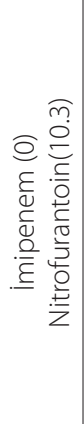 & 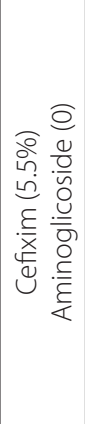 & 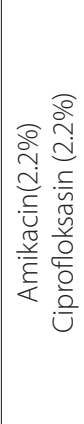 & 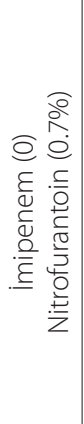 & 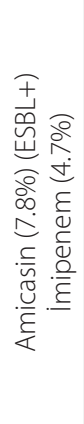 & 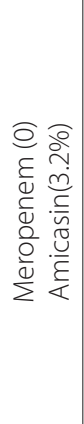 & 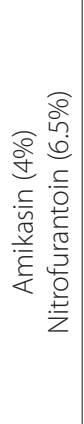 & 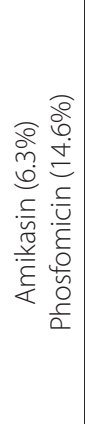 & 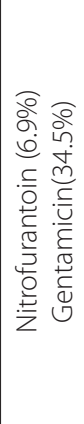 & 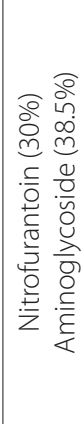 & 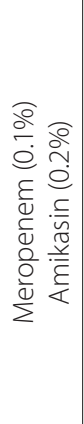 & 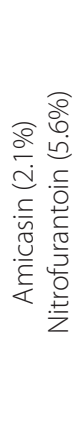 \\
\hline 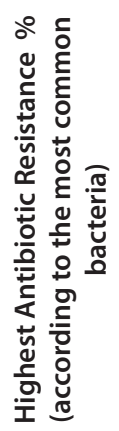 & 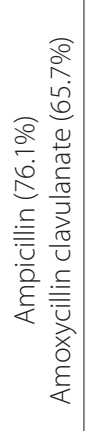 & 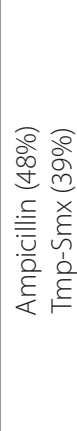 & 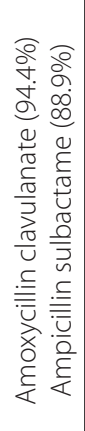 & 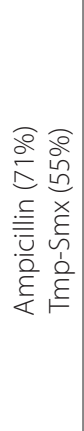 & 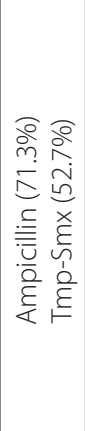 & 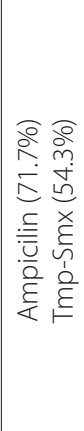 & 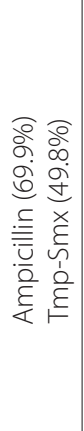 & 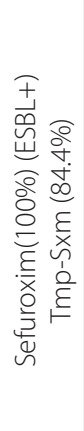 & 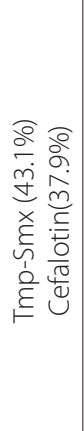 & 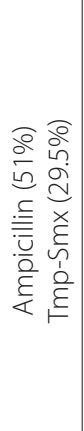 & 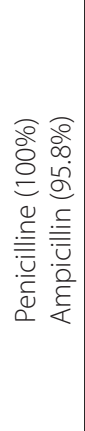 & 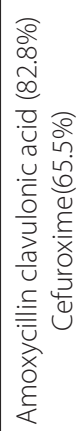 & 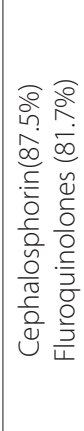 & 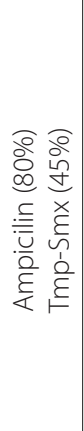 & 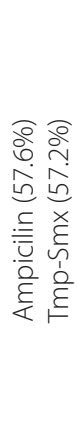 \\
\hline 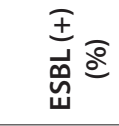 & & ' & $\stackrel{m}{n}$ & & ' & ' & $\begin{array}{l}\stackrel{0}{0} \\
\stackrel{1}{0} \\
\vdots \\
0\end{array}$ & 仓̊. & & & & & ' & & $\stackrel{\sigma}{\dot{I}}$ \\
\hline 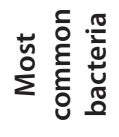 & نे & $\begin{array}{l}\overline{\bar{o}} \\
\dot{\omega}\end{array}$ & 訔 & $\begin{array}{l}\overline{\bar{\sigma}} \\
\text { Lu }\end{array}$ & $\begin{array}{l}\overline{\bar{z}} \\
\text { Lu }\end{array}$ & 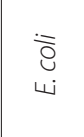 & $\begin{array}{l}\overline{\bar{\sigma}} \\
\text { u. }\end{array}$ & ن & $\begin{array}{l}\overline{\bar{z}} \\
\text { ü }\end{array}$ & نu & $\begin{array}{l}\overline{\bar{u}} \\
\text { ü }\end{array}$ & $\begin{array}{l}\tilde{J} \\
\stackrel{0}{5} \\
\sigma \\
\sim\end{array}$ & $\begin{array}{l}\overline{\bar{D}} \\
\dot{u}\end{array}$ & $\begin{array}{l}\overline{\bar{u}} \\
\text { ü }\end{array}$ & $\begin{array}{l}\overline{\bar{d}} \\
\dot{u}\end{array}$ \\
\hline 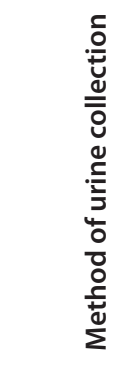 & 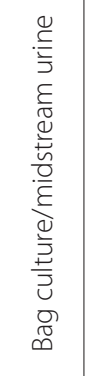 & 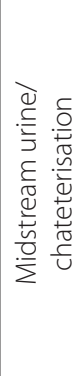 & 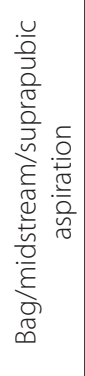 & 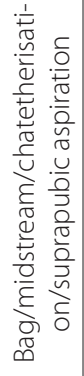 & 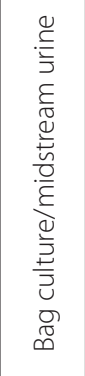 & 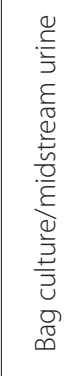 & 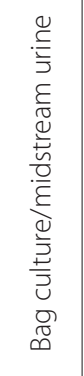 & 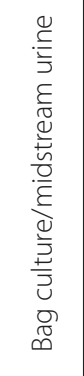 & 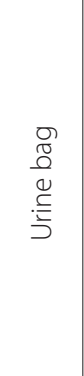 & 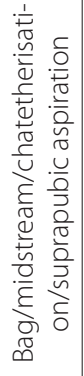 & 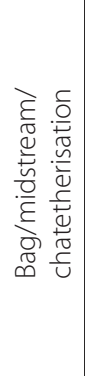 & 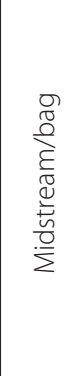 & 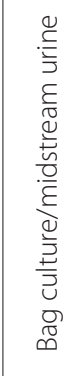 & 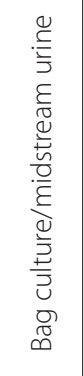 & 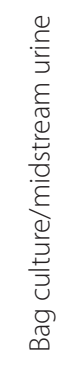 \\
\hline 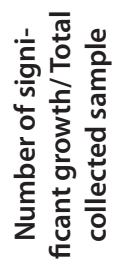 & $\begin{array}{l}\omega \\
0 \\
\hat{0} \\
\curvearrowright \\
\infty \\
\infty \\
\infty\end{array}$ & $\stackrel{上}{上}$ & 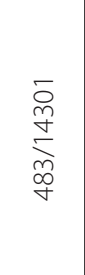 & 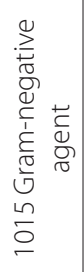 & مે & in & $\underset{\sim}{\stackrel{J}{\sim}}$ & ָे & 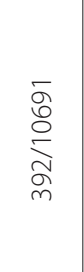 & $\overline{\mathrm{N}}$ & 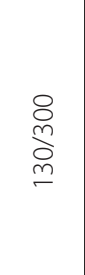 & $\stackrel{n}{\sim}$ & 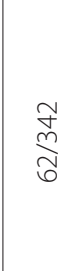 & 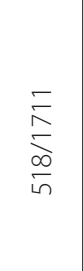 & 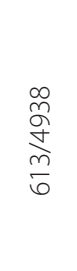 \\
\hline 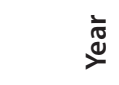 & $\stackrel{\infty}{\stackrel{N}{~}}$ & $\stackrel{\text { }}{\stackrel{\sim}{~}}$ & $\stackrel{\circ}{\circ}$ & $\stackrel{\circ}{\stackrel{\sim}{v}}$ & $\stackrel{\circ}{\stackrel{N}{*}}$ & $\overline{\bar{v}}$ & $\stackrel{\sim}{\tilde{D}}$ & $\bar{i}$ & $\underset{⿱ 亠}{\stackrel{D}{~}}$ & $\underset{\sim}{\stackrel{\nabla}{\sim}}$ & $\stackrel{\operatorname{Ln}}{\bar{v}}$ & $\stackrel{\circ}{\stackrel{0}{v}}$ & $\bar{i}$ & $\stackrel{\infty}{\bar{v}}$ & ণ্ণ \\
\hline & $\begin{array}{l}\frac{\bar{m}}{\sigma} \\
\frac{\vec{U}}{U} \\
\frac{N}{E} \\
\frac{E}{U}\end{array}$ & 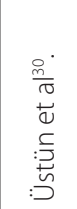 & 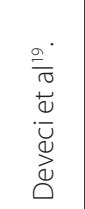 & 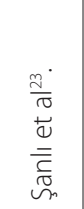 & 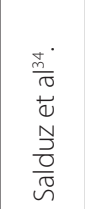 & $\begin{array}{l}\frac{0}{0} \\
\frac{0}{0} \\
\frac{0}{0} \\
\frac{\pi}{8} \\
\frac{0}{0} \\
\frac{0}{4}\end{array}$ & 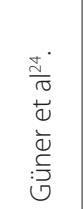 & 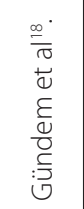 & $\begin{array}{l}\frac{\infty}{\pi} \\
\frac{0}{0} \\
\frac{0}{0} \\
0 \\
0 \\
0\end{array}$ & 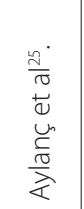 & $\begin{array}{l}\frac{m}{\sigma} \\
\frac{\pi}{U} \\
\frac{0}{d} \\
\mathbb{U} \\
\mathbb{N}\end{array}$ & 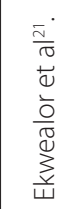 & 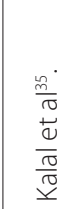 & 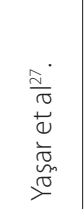 & 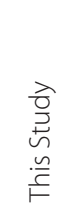 \\
\hline
\end{tabular}


Ethics Committe Approval: Ethical approval for this study was obtained from Kafkas University Faculty of Medicine Ethical Committee (Decision Number: 08576354-050-99/144, Date: 25.07.2018)

Informed Consent: The verbal and written informed consent was taken from the children's mothers.

Peer-review: Externally peer-reviewed.

Author Contributions: Consept - HBB; Design - HBB; Supervision ÇEB, HBB; Resources - ÇEB, HBB; Data Collection and/or Processing - ÇEB, HBB; Analysis and/or Interpretation - ÇEB, HBB; Literature Review- ÇEB, HBB; Writing - ÇEB, HBB; Critical Review - ÇEB, HBB.

Conflict of Interest: No conflict of interest was declared by the authors.

Financial Disclosure: The authors declared that this study has received no financial support.

\section{References}

1. Okarska-Napierała M, Wasilewska A, Kuchar E. Urinary tract infection in children: Diagnosis, treatment, imaging-Comparison of current guidelines. J Pediatr Urol 2017;13:567-73. [CrossRef]

2. Elder JS. Urinary tract infections. In: Kliegman RM, Stanton BF, St Geme JW (eds ). Nelson Textbook of Pediatrics. $19^{\text {th }}$ ed. Philadelphia: Elsevier Saunders, 2011:1829-34. [CrossRef]

3. Korbel $L$, Howell $M$, Spencer JD. The clinical diagnosis and management of urinary tract infections in children and adolescents. Paediatr Int Child Health 2017;37:273-9. [CrossRef]

4. O'Brien K, Stanton N, Edwards A, Hood K, Butler CC. Prevalence of urinary tract infection (UTI) in sequential acutely unwell children presenting in primary care: exploratory study. Scand J Prim Health Care 2011;29:19-22. [CrossRef]

5. Bader MS, Loeb M, Brooks AA. An update on the management of urinary tract infections in the era of antimicrobial resistance. Postgrad Med 2017;129:242-58. [CrossRef]

6. Özen M. İrar yolu enfeksiyonları. Kara A (çeviri editörü). Çocuk Enfeksiyon Hastalıkları Klinik Rehberi. Istanbul: Nobel Tıp Kitapevleri, 2008:102-7. [CrossRef]

7. Tapısız A. Üriner enfeksiyonlarda antibiyotik kullanımı. 8. Ulusal Çocuk Enfeksiyon Hastalıkları Kongresi, 10-14 Mayıs 2013, Antalya, konuşma metinleri ve bildiri özetleri kitabı, 37-41. [CrossRef]

8. Wald ER. Cystitis and pyelonephritis. In: Feigin RD, Cherry JD, Demler-Harrison GJ (eds). Textbook of Pediatric Infectious Diseases. 6th ed. Philadelphia: Saunders, 2009:554-69. [CrossRef]

9. Flores-Mireles AL, Walker JN, Caparon M, Hultgren SJ. Urinary tract infections: epidemiology, mechanisms of infection and treatment options. Nature Rev Microbiol 2015;13:269-84. [CrossRef]

10. Ipek IO, Bozaykut A, Arman DC, Sezer RG. Antimicrobial resistance patterns of uropathogens among children in Istanbul, Turkey. Southeast Asian J Trop Med Public Health 2011;42:355-62. [CrossRef]

11. Senel S, Karacan C, Erkek N, Göl N. A Single-center experience of antimicrobial resistance patterns in pediatric urinary tract infection. Med Princ Pract 2010;19:359-63. [CrossRef]

12. Yılmaz R, Karaaslan E, Özçetin M, Arslan B, Kilinc M, Kazanci NO, et al. Çocuklarda idrar yolları enfeksiyonu etkenleri ve antibiyotik duyarlılıkları. J Contemp Med 2012;2:17-21. [CrossRef]
13. Yuksel S, Ozturk B, Kavaz A, Ozçakar ZB, Acar B, Güriz H, et al. Antibiotic resistance of urinary tract pathogens and evaluation of empirical treatment in Turkish children with urinary tract infections. Int J Antimicrob Agents 2006;28:413-6. [CrossRef]

14. Güneş H, Donma MM, Nalbantoğlu B. Namık Kemal Üniversitesi Araştırma ve Uygulama Hastanesi'ne başvuran çocuklarda idrar örneklerinden izole edilen etkenler ve antibiyotik direnç durumları. Cumhuriyet Med J 2013;35:1-8. [CrossRef]

15. Cebe A, Ayvaz A, Yıldız N, Çetinkaya S. Sivas ilinde çocukluk çağı idrar yolu enfeksiyonlarında idrar kültür sonuçları: Illk tedavi seçimi nasıl olmalıdır? Van Tip Dergisi 2008;15:7-12. [CrossRef]

16. Beyene G, Tsegaye W. Bacterial uropathogens in urinary tract infection and antibiotic susceptibility pattern in jimma university specialized hospital, southwest ethiopia. Ethiop J Health Sci 2011;21:141-6. [CrossRef]

17. Kuzucu Ç, Yetkin F, Görgeç S. Genişlemiş spektrumlu beta-laktamaz üreten Escherichia coli ve Klebsiella spp. suşlarının ertapenem ve diğer karbapenemlere karşı duyarlılıklarının araştırılması. Mikrobiyol Bul 2011;45:28-35. [CrossRef]

18. Gündem NS, Çıkman A, Gülhan B. Extended spectrum beta-lactamase (ESBL) production and antibiotic resistances of Escherichia coli and Klebsiella spp. strains isolated from urine cultures. J Clin Exp Invest 2013;4:56-62. [CrossRef]

19. Deveci Ö, Yula E, Tekin A. İdrar kültürlerinden izole edilen Escherichia coli suşlarında beta-laktamaz sıklığı ve antibiyotik direnci. J Clin Exp Invest 2010;1:182-6. [CrossRef]

20. Aykan B, Çiftci iH. Türkiye'de idrar kültürlerinden izole edilen Escherichia coli suşlarının antibiyotiklere direnç durumu: bir meta-analiz antibiotic resistance patterns of Escherichia coli strains isolated from urine cultures in Turkey: a meta-analysis. Mikrobiyol Bul 2013;47:603-18. [CrossRef]

21. Ekwealor PA, Ugwu MC, Ezeobi I. Antimicrobial evaluation of bacterial isolates from urine specimen of patients with complaints of urinary tract infections in Awka, Nigeria. Int J Microbiol 2016:1-6. [CrossRef]

22. Kayaş L, Yolbaş I, Ece A, Kayaş Y, Balık H, Kocamaz H. Causative agents and antibiotic susceptibilities in children with urinary tract infection. $J$ Microbiol Infect Dis 2011;1:17-21. [CrossRef]

23. Şanlı KZ, Türel Ö, Hatipoğlu N, Yılmaz A, Şiraneci R. Çocuk idrar örneklerinden izole edilen gram negatif bakteriler ve antibiyotik duyarlılıkları. JOPP Derg 2011;3:27-34. [CrossRef]

24. Güner ŞN, Göktürk B, Bayrakçı US, Baskın E. Çocuklarda idrar örneklerinden saptanan toplum kaynaklı gram-negatif mikroorganizmaların dağılımı ve 2003-2010 yılları arasında antibiyotik direncindeki artışın değerlendirilmesi. Türk Ped Arş 2012;47:107-3. [CrossRef]

25. Aylanç $H$. Children with urinary tract isolated from cultures of microorganisms and antibiotic resistance rates. Anatol J Clin Investig 2014;8:121-5. [CrossRef]

26. Erdoğan $H$, Arslan $H$. Çocuklarda toplum kaynaklı üriner sistem infeksiyon etkenleri ve antibiyotik duyarlılıkları. Nobel Med 2011;7:15-8. [CrossRef]

27. Yaşar A, Yaşar B, Özkan EA, Savcı Ü. Yozgat yöresi çocukluk çağı idrar yolu enfeksiyonuna en sık sebep olan etkenler ve antibiyotik dirençleri. Bozok Tip Derg 2018;8(2):53-8. [CrossRef]

28. Çoban B, Ülkü N, Kaplan H, Topal B, Erdoğan H, Baskın E. Five-year assessment of causative agents and antibiotic resistances in urinary tract infections. Türk Ped Arş 2014;49:124-9. [CrossRef]

29. Mir S, Dönmez O, Kabasakal C, Sönmez F, Cura A. Çocukluk çağı idrar yolu enfeksiyonlarında ilk tedavi seçeneği ne olmalıdır? Türk Nefrol Diyal Transplant Derg 1997;2:149-53. [CrossRef] 
30. Üstün C, Demir YS, Demir S, Demirören S, Kurtoğlu MG. Pediyatrik yaş grubu toplum kökenli üriner sistem enfeksiyonlarından izole edilen Escherichia coli ve Klebsiella spp. suşlarının in-vitro antibiyotik direnci. ANKEM Derg 2009;23:155-60. [CrossRef]

31. Temiz H, Akkoç H, Gül K. Laboratuarımızda idrar kültürlerinden izole edilen gram negatif bakterilerde antibiyotiklere direnç. Dicle Tıp Dergisi 2008;35:234-9. [CrossRef]

32. Saeed CH, AL-Otraqchi KIB, Mansoor IY. Prevalence of urinary tract infections and antibiotics susceptibility pattern among infants and young children in Erbil city. Zanco J Med Sci 2015;19:915-22. [CrossRef]

33. Salduz ZiY, Yiğit Ö. Antibiotic susceptibility of bacteria isolated from children with urinary tract infection. J Pediatr Inf 2010;4:138-42. [CrossRef]

34. Kalal BS, Patel RB. Microbiological and antimicrobial profile of urinary tract infection in children from a teaching hospital in South India. J Pediatr Inf 2017;11:19-22. [CrossRef]
35. Özdem B. Which antibiotics should be the first choice for empiric therapy of urinary tract infections? Ankara Med J 2016;16:41-50. [CrossRef]

36. Yenişehirli $G$, Yenişehirli A, Bulut $Y$, Özveren G. Idrar kültürlerinden izole edilen enterokok suşlarında antimikrobiyal direnç. Klimik Dergisi 2016;29:112-6. [CrossRef]

37. Barış A, Bulut ME, Öncül A, Bayraktar B. Distribution of clinical isolates at species level and their antibiotic susceptibilities in intensive care units patients. J Turk Soc Intens Care 2017;15:21-7. [CrossRef]

38. Mete E, Kaleli I, Cevahir N, Demir M, Akkaya Y, Satılmış ÖK. Evaluation of virulence factors in enterococcus species. Mikrobiyol Bul 2017;51:10114. [CrossRef]

39. Kalaycı Ö, Yurtsever SG, Güngör S, Uzun B, Kurultay N. Evaluation of in vitro antibiotic sensitivity of enterococci lisolated from urine samples. Klimik Dergisi 2011;24:105-7. [CrossRef] 